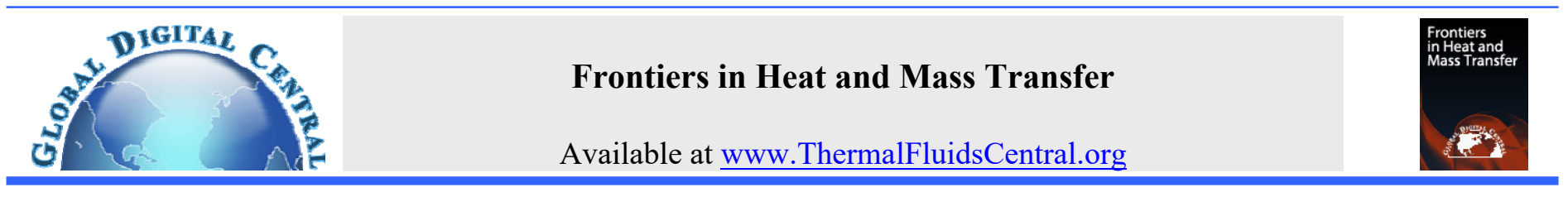

\title{
HEAT EXCHANGES INTENSIFICATION THROUGH A FLAT PLAT SOLAR COLLECTOR BY USING NANOFLUIDS AS WORKING FLUID
}

\author{
A. Maouassi ${ }^{a, b *}$, A. Baghidja ${ }^{a, b}$, S. Douad ${ }^{c}$, N. Zeraibi ${ }^{c}$ \\ ${ }^{a}$ Renewable Energy and Sustainable Development Laboratory (LERDD), University of Constantine1, 25000 Constantine, Algeria. \\ ${ }^{b}$ Department of Mechanical Engineering, University of Constantine 1, 25000 Constantine, Algeria. \\ ${ }^{c}$ Department of Transportation of Hydrocarbons, University of Boumerdès, 35000 Boumerdès, Algeria.
}

\begin{abstract}
This paper illustrates how practical application of nanofluids as working fluid to enhance solar flat plate collector efficiency. A numerical investigation of laminar convective heat transfer flow throw a solar collector is conducted, by using $\mathrm{CuO}$-water nanofluids. The effectiveness of these nanofluids is compared to conventional working fluid (water), wherein Reynolds number and nanoparticle volume concentration in the ranges of $25-$ 900 and $0-10 \%$ respectively. The effects of Reynolds number and nanoparticles concentration on the skin-friction and heat transfer coefficients are presented and discussed later in this paper. Results show that the heat transfer increases with increasing both nanoparticles concentration and Reynolds number, where nanofluid $\mathrm{CuO}$-water gives best improvement in terms of heat transfer.

Keywords: flat plat solar collector, nanofluids, heat transfer, $\mathrm{CuO}$ nanoparticles.
\end{abstract}

\section{INTRODUCTION}

Heat transfer is a very important phenomenon in energy systems, the field of renewable energies is one of these systems, it take a major interest around the world because it will be replaces the conventional energy sources (Hussein, 2015). Today, the most of the research is oriented towards this axis, where the improvement of the efficiency of these thermal systems based mainly on the energy efficiency of solar collectors (Chabane et al, 2013). In order to improve their efficiency and in addition to conventional methods such as geometric modification (Karwa and Chauhan, 2010; Bhushan and Singh, 2011; Lanjewar et al. 2011; Promvonge et al., 2012; Garcia et al., 2013; Azmi et al., 2014; Yadav et al.(2013; Nanan et al., 2014; Sandhu et al., 2014) and Solar selective coatings (Juang et al., 2010; Nuru et al., 2012; Khamlich et al., 2013; Kumar et al., 2014), a new technology was used based on the replacement of the classical heat transfer fluid by another class having higher thermal properties (Amoura et al., 2012) .

The idea to improve thermo-physical properties of conventional fluids is adding solid particles with a high thermal characteristics and nano-size, inside basic fluid (working fluid). This new generation of fluids named Nanofluids; this term was introduced first by Choi (1995), and usually stills use to characterize this colloidal suspension type. After these initiative studies of the ARGONNE laboratory group (Eastman et al., 1997; Choi, 2001; Keblinski et al., 2002), several experimental and numerical studies have been carried out in order to analyze and understand the hydrothermal behavior of this new class of working fluids.

First, an experimental studies are done on the thermo-physical properties of nanoluides (Eastman, 2001; Choi et al., 2001; Patel et al., 2003), which observe that the thermal conductivity of nanofluids are very high compared to that of conventional fluid and exceed those predicted by conventional approaches. After these results, Keblinski et al. (2002), Jang and Choi (2004) and then Evans (2006) developed thermal conductivity classic model of the nanofluid, where they introduced the effect of the Brownian motion and nanoparticles agglomeration effect, which explain the important improvement.

In recent years, a wide research work has been done in this research area to understand the thermo-hydraulic behavior of this new heat transfer fluid generation, they proved that nanoparticles suspension within the conventional heat transfer fluid increases its thermal conductivity and consequently improves the heat transfer (Rawi et al., 2017; Boulahia et al., 2017; Wakif et al., 2017; Boulahia et al., 2017; Ramesh and Gireesha, 2017).

Al-Rashed et al. (2017) studied the effect of magnetic field on natural convection inside a cubical cavity filled with CNT - water nanofluide; they found that for all the Rayleigh numbers the Bejan number increase by increasing nanoparticles volume concentration. Mixed convective incompressible flow of nanofluid through a vertical channel in presence of magnetite field has been investigated by Srinivasacharya and Shafeeurrahaman (2017), in the same context, Sravan Kumar and Rushi Kumar (2017), Govindaraju et al. (2017) and Sathish Kumar et al. (2017) carried out a numerical study on free convection heat transfer of nanofluids over a stretching sheet in the presence of a uniform magnetic field.

All the previous studies show that the improvement of the heat transfer coefficient is related to the presence of nanofluids. Despite the fact that there is no commercial solar collector available that uses these nanofluids, there are experimental studies that confirm its effectiveness by adding nanoparticle to improve the thermal efficiency, Natarajan et al. (2009) found that if the nanofluids are used as working fluids, the energy efficiency of solar water heaters increases significantly compared to conventional fluids. On the other hand, the dispersion of the nanoparticles gives an important increase in the heat transfer coefficient (Faizal et al., 2013; Sokhansefat et al., 2014; He et al., 2015; Menbari et al., 2016; Nasrin et al. 2016). Hence, they found that it is

\footnotetext{
${ }^{*}$ Corresponding author.Email: maouassi.ammar@umc.edu.dz
} 
possible to reduce the exchange surface and improve the efficiency of these devices, which confirms the results of Natarajan et al. (2009). Maouassi et al. (2017) carried out a numerical study of forced convection heat transfer through a flat plate solar collector, the geometry is tested for $3 \mathrm{D}$ case, where water and $\mathrm{SiO}_{2}-\mathrm{H}_{2} \mathrm{O}$ nanofluid are used as a working fluid, the results obtained show that the increase of nanoparticles volume concentration gives an improvement in heat transfer rate reach $13.7 \%$ for $10 \%$ of nanoparticles volume concentration.

In this paper, we present a comparative study of heat transfer of nanofluid (CuO-water) flows through a solar flat plate collector. In the first part, we describe the problem and present the boundary conditions. After grid independence study, then we validated the results by comparing them with previous literature reports.

The key part of this work is to involve the simulation with the interpretation of numerical results obtained for this case, where the effect of nanoparticles are shown for various volume concentration and Renolds number, and studied systematically. At the end, this paper is footed by conclusion which summarizes the main results obtained.

\section{PROBLEM DESCRIPTION AND MATHEMATICAL FORMULATION}

The flow domain consists of an absorber plate and circular absorber tube. The absorber plate is covered with glass plate with an air gap. Design parameters and fixed geometric parameters have been taken similar to Maouassi et al. (2017), as indicated in Table. I.

Table 1 Design parameters of the solar collector.

\begin{tabular}{|l|c|c|c|c|}
\hline & $\begin{array}{l}\text { absorber plate } \\
(\mathrm{mm})\end{array}$ & $\begin{array}{l}\text { Tube } \\
(\mathrm{mm})\end{array}$ & $\begin{array}{l}\text { Glass plate } \\
(\mathrm{mm})\end{array}$ & $\begin{array}{l}\text { air gap } \\
(\mathrm{mm})\end{array}$ \\
\hline length & 1000 & 1010 & 1000 & 1000 \\
\hline wide & 150 & - & 150 & 150 \\
\hline diameter & - & 10 & - & - \\
\hline thickness & 2 & 1 & 2 & 3 \\
\hline
\end{tabular}

The heat transfer of nanofluide under laminar flow inside the absorber tube, as shown in Fig. 1, the flow is assumed steady and the fluid possesses uniform axial velocity $\mathrm{V}_{0}$ and temperature $\mathrm{T}_{0}$ profiles at the inlet of tube.

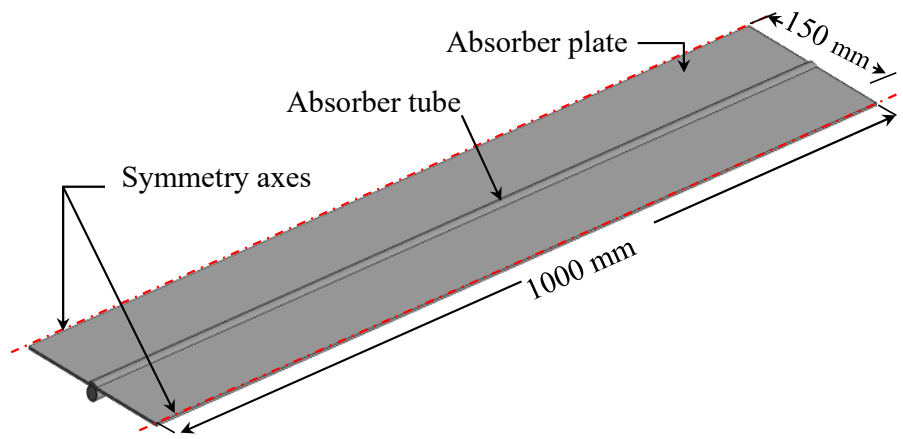

Fig. 1 Geometrical representation of the studied problem

The nanoparticles used in practical applications of heat exchange are very thins $(\leq 50 \mathrm{~nm})$, then the liquid-particle mixture may easily be fluidized and considered as a homogenous single-phase fluid (Xuan et al., 2000). By assuming negligible thermal equilibrium and slip between the phases, the apparent thermal properties of nanofluids can be estimated by using classical relationships of two-component mixture (Pak et al., 1998), and the mixture considered as a conventional singlephase fluid (Xuan et al., 2000) .

Under the previous assumptions, the governing equations including the two-dimensional transient equations of the momentum, energy and continuity for an incompressible flow are expressed in the following format: $\rho_{n f} \frac{\partial\left(u_{i} u_{j}\right)}{\partial x_{j}}=-\frac{\partial P}{\partial x_{i}}+\frac{\partial}{\partial x_{j}}\left(\mu_{n f} \frac{\partial u_{i}}{d x_{j}}\right)$

$\frac{\partial}{\partial x_{j}}\left(u_{j} T\right)=\frac{k_{n f}}{\rho_{n f} C p_{n f}} \frac{\partial}{\partial x}\left(\frac{\partial^{2} T_{l}}{d x_{j}^{2}}\right)$

$\frac{\partial}{\partial x_{j}}\left(\rho_{n f} u_{j}\right)=0$

The physical properties of nanofluid, nanofluid density $\rho_{\mathrm{nf}}$ (Zhou et al., 2008), viscosity $\mu_{\mathrm{nf}}$ (Brinkman et al., 1952), Thermal conductivity $\mathrm{k}_{\mathrm{nf}}$ (Maxwell et al., 1891) and Nanofluid specific heat $\mathrm{Cp}_{\mathrm{nf}}$ (Xuan et al., 2000) are given with the below equations:

$\rho_{n f}=\rho_{s} \phi+\rho_{f}(1-\phi)$

$\mu_{n f}=\mu_{n f}(1+2.5 \phi) \mu_{f}$

$k_{n f}=\frac{k_{s}-2 k_{f}-2 \phi\left(k_{f}-k_{s}\right)}{k_{s}+2 k_{f}+\phi\left(k_{f}-k_{s}\right)} k_{f}$

$C p_{n f}=\frac{\rho_{s} C p_{s} \phi+\rho_{f} C p_{f}(1-\phi)}{\rho_{n f}}$

The thermo-physical properties of the nanofluid compositions used in this study are listed in Table 2.

For boundary conditions and operating parameters are taken similar to Maouassi et al., 2017). For inlet 'velocity inlet' boundary condition is specified and an 'outflow' condition is specified at the outlet for the water domain. Wall boundary conditions used to bound fluid and solid regions. The interface between water and absorber tube is defined as coupled wall condition. In the top of collector a constant solar heat flux equal to $800 \mathrm{~W} / \mathrm{m}^{2}$ are imposed.

Table 2 Thermo-physical properties of nanofluide Amoura et al., 2012).

\begin{tabular}{|l|c|c|}
\hline $\begin{array}{l}\text { Thermo-physical } \\
\text { properties }\end{array}$ & Base fluid (Water) & Nanoparticles (CuO) \\
\hline$\rho\left(\mathrm{kg} / \mathrm{m}^{3}\right)$ & 1000 & 6350 \\
\hline $\mathrm{k}(\mathrm{W} / \mathrm{m} \mathrm{K})$ & 0.613 & 69 \\
\hline $\mathrm{Cp}(\mathrm{J} / \mathrm{kg} . \mathrm{K})$ & 4183 & 535 \\
\hline$\mu\left(\mathrm{kg} \mathrm{m} \mathrm{m}^{-1}\right)$ & $1.00310^{-3}$ & - \\
\hline
\end{tabular}

The thermo-physical quantities of principal interest are the skin friction coefficient $\left(\mathrm{C}_{\mathrm{f}}\right)$, and the local Nusselt number $\left(\mathrm{Nu}_{\mathrm{x}}\right)$.

\subsection{The Skin Friction Coefficient}

The skin friction coefficient for the fully developed laminar flow in a circular tube is given by

$C_{f}=\tau_{s} \frac{\rho u_{m}^{2}}{2}$

Where $\tau$ s is local shear stress, and um is the mean velocity given by

$u_{m}=\frac{\int_{0}^{R} \rho u 2 \pi r d r}{\int_{0}^{R} \rho 2 \pi r d r}=\frac{2}{R^{2}} \int_{0}^{R} u r d r$

\subsection{Local Nusselt Number}

The Nusselt number, which represents the dimensionless temperature gradient at the surface (Eq. 14) and provides a measure of the convection coefficient, is defined as 


$$
N u_{x, n f}=\frac{h_{x, n f} D}{k_{f}}
$$

Near the wall of tube absorber, the surface heat flux is equal to the convective flux the fluid (no-slip condition), which is expressed by Newton's law of cooling

$$
q_{s f}^{\prime \prime}=q_{c o n v}^{\prime \prime}=h_{x, n f}\left(T_{x, w}-T_{x, m}\right)
$$

Where $T_{x,}, T_{x, m}$ are the local wall temperature and mean fluid temperature respectively, the mean temperature of a fluid flowing in a circular pipe of radius $R$ is given by

$T_{m}=\frac{\int_{0}^{R} \rho \text { CрuT } 2 \pi r d r}{\int_{0}^{R} \rho C p u 2 \pi r d r}=\frac{2}{u_{m} R^{2}} \int_{0}^{R} u T r d r$

The local heat flux at the surface is obtained by applying Fourier's law to the fluid at $r=\mathrm{R}$

$$
q_{s f}^{\prime \prime}=k_{n f}\left(\left.\frac{\partial T}{\partial r}\right|_{r=R}\right)_{s f}
$$

By combining the foregoing equations (Eq. 11 and 13), we obtain the local convection coefficient

$h_{x, n f}=-\frac{k_{n f}}{T_{x, w}-T_{x, m}}\left(\left.\frac{\partial T}{\partial r}\right|_{r=R}\right)_{s f}$

And the Nusselt number of nanofluid are given by

$N u_{x, n f}=-\frac{2 k_{n f}}{k_{f}} \frac{R}{T_{x, w}-T_{x, m}}\left(\left.\frac{\partial T}{\partial r}\right|_{{ }_{r}=R}\right)_{s f}$

The rate of the improvement in the heat transfer coefficient is calculated as follows

$N u(\%)=-\frac{N u_{n f}-N u_{\text {water }}}{N u_{\text {water }}} \times 100$

\section{NUMERICAL METHOD AND CODE VALIDATION}

To conduct numerical simulation, the computational domain was meshed using finite volume method, by using a preprocessor of FLUENT called GAMBIT (version 2.4.6). This simulation based on the solver of steady state implicit pressure integrated in FLUENT software (version 6.3). And the Governing partial differential equations, for mass and momentum, are solved for the steady incompressible flow. The velocity-pressure coupling is affected through SIMPLE algorithm developed by Patankar (1980). Second order upwind schemes were chosen for the solution schemes, and laminar flow condition was used.

\subsection{Meshing and Grid Independence Study}

The computational domain was meshed and done by using appropriate grid cells, with suitable size. Three dimensional computational domains are built and used, as shown in Figure 2. To solve the previous system of governing equations (1-3), the computational domain was meshed with the finite control volume method which has been successfully used by several authors (Beyers et al., 2001) and Maïga et al. (2004).

Several non-uniform grids have been thoroughly tested to ensure the accuracy and the consistency of numerical results, which has shown that the $40 \times 60 \times 500$ non-uniform grid $(32,24$ and 155 nodes, respectively, along the radial, tangential and axial directions) appears satisfactory for the absorber tube (Figure 3); with refining mesh near the tube wall and the entrance region.

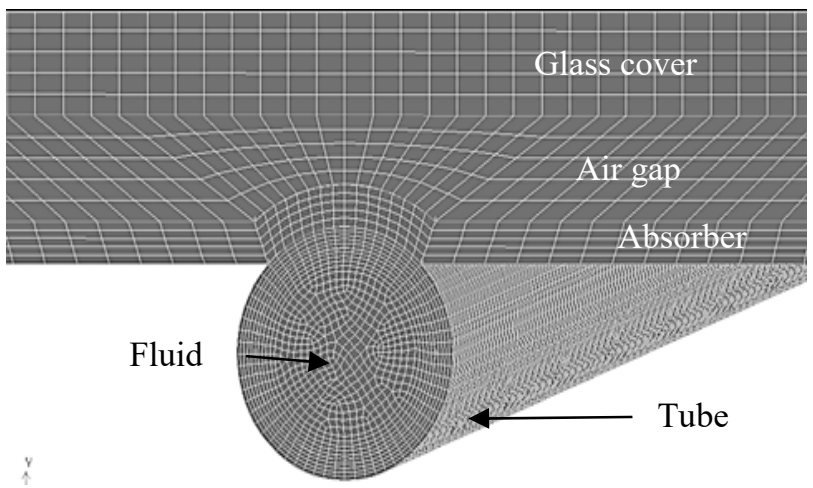

Fig. 2 Mesh validation curves for the outlet temperature evolution.

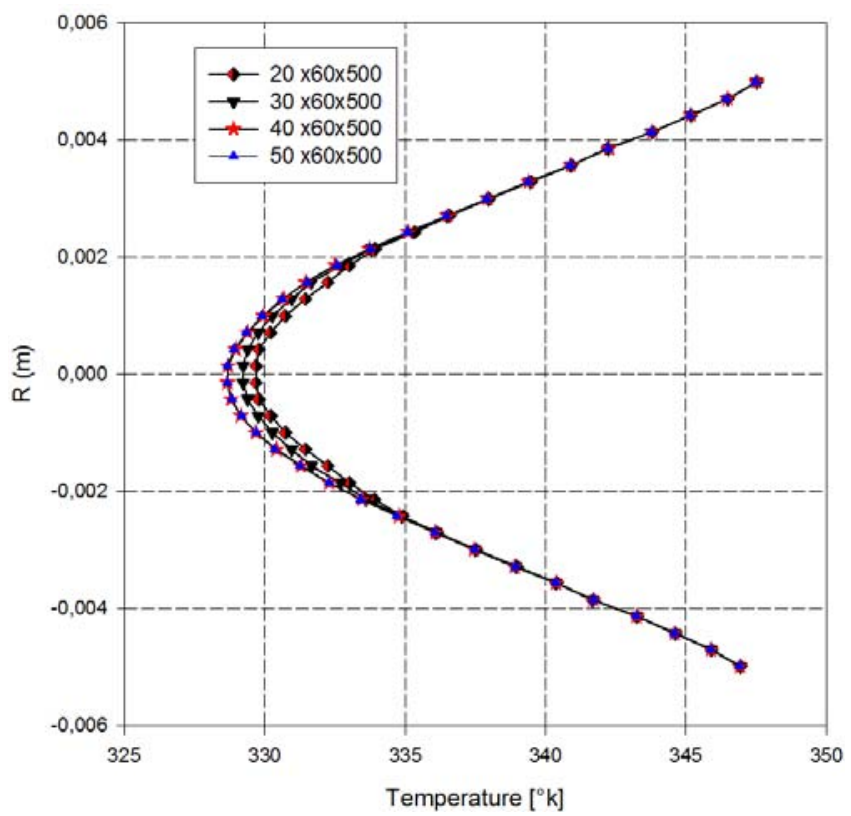

Fig. 3 Mesh validation curves for the outlet temperature evolution.

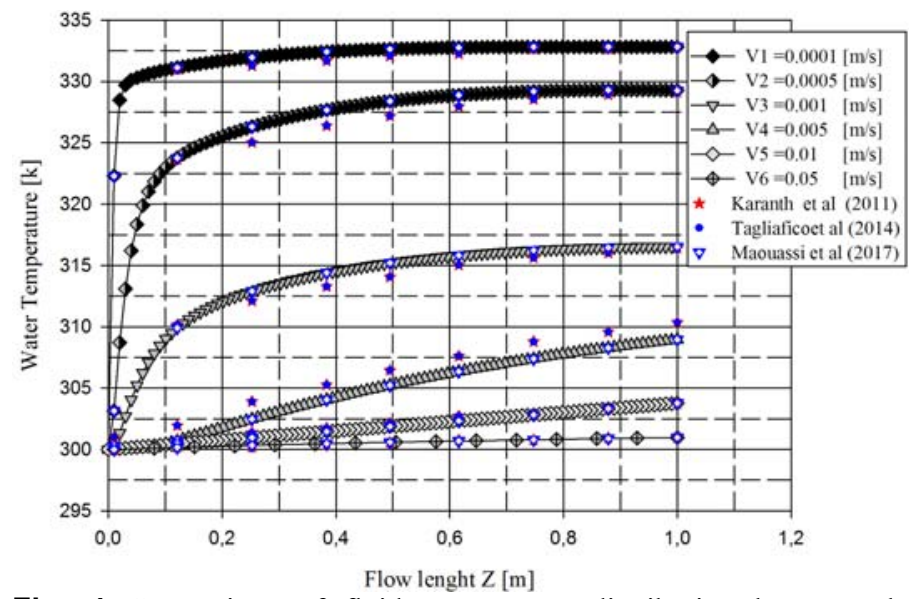

Fig. 4 Comparison of fluid temperature distribution between the present results and those reported in the literature. 

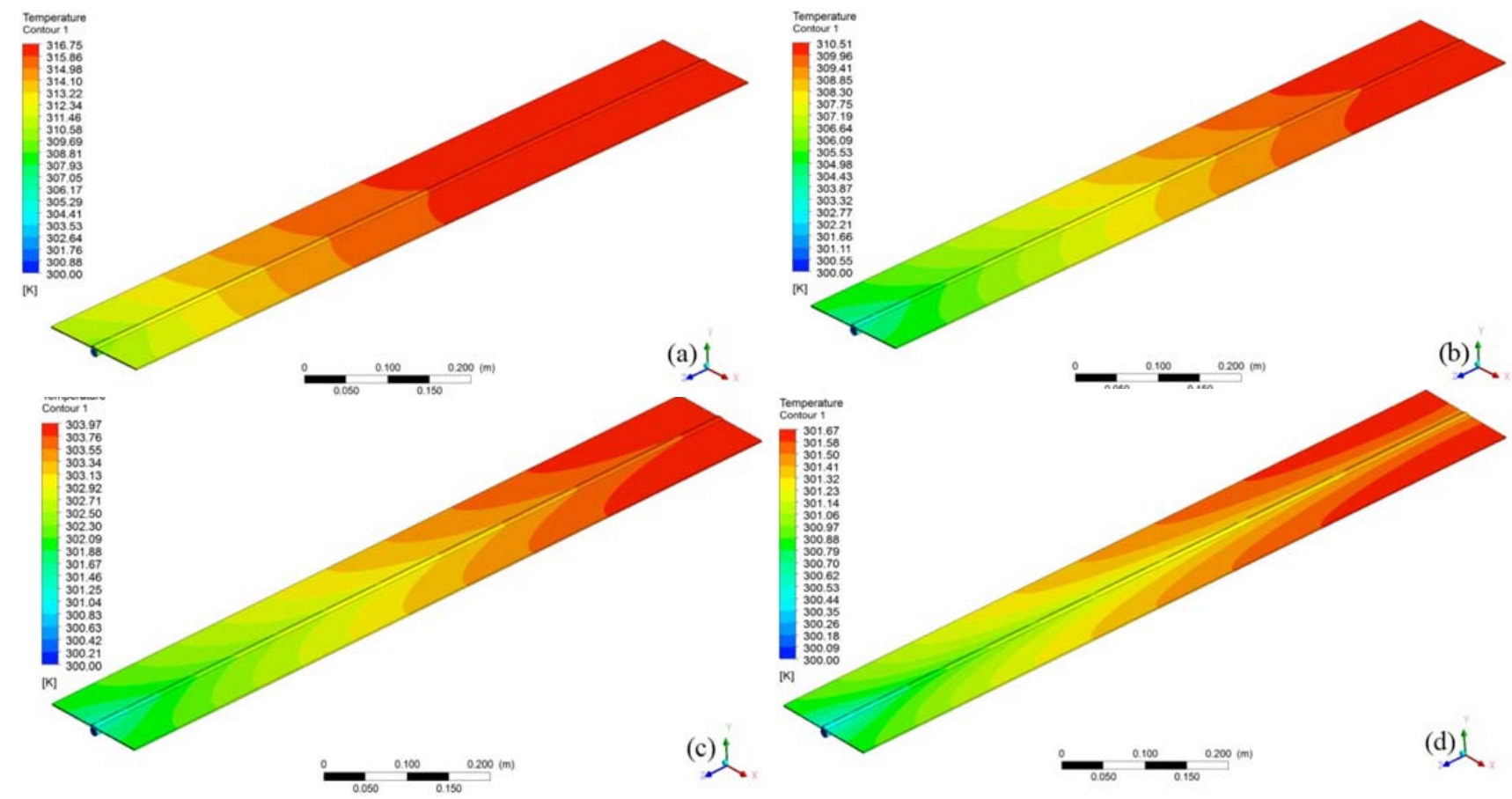

Fig. 5 Temperature distribution on the absorber for (a) $V=0.001 \mathrm{~m} / \mathrm{s}$, (b) $V=0.005 \mathrm{~m} / \mathrm{s}$, (c) $V=0.01 \mathrm{~m} / \mathrm{s}$, (d) $V=0.05 \mathrm{~m} / \mathrm{s}$.

\subsection{Code Validation}

In order to validate the present results, the axial temperatures evolution of the working fluid along the absorber tube presented by Karanth et al. (2011), Tagliafico et al. (2014) and Maouassi et al. (2017).

The comparison results are exhibited in Fig. 4. It can be seen from this results that, a very good matching between our results and those of the authors; which gives confidence in the numerical method employed Fig. 5 illustrate the temperature evolution distribution on the absorber plate for different values of inlet velocity $(\mathrm{V}=0.001$ to $0.05 \mathrm{~m} / \mathrm{s})$ presented by Maouassi et al. (2017).

\section{NUMERICAL METHOD AND CODE VALIDATION}

We study the nanofluids heat transfer flow inside an absorbent tube, where he heated by the absorbent plaque. We consider the flow regime as laminar, and varying the number of Reynolds between 25 and 900, for the different nanoparticles concentrations $(1 \%, 3 \%, 5 \%$, and $10 \%)$. Then we plot the results, pressure drop coefficient and Nusselt number.

\subsection{Pressure Drop Coefficient}

Key parameter of the present study is the volume concentration of nanoparticles. Fig. 6 exhibits the effect of the nanoparticles volume percentage " $\phi "$ on the skin friction coefficient, for each Reynolds number.

It is clearly noted that there is a slight increase in skin friction coefficient (Cf) when the Reynolds number is low ( $\mathrm{Re} \leq 100)$, this slight increase in $\mathrm{Cf}$, it is due to the presence of the nanoparticles and lower fluid flow velocities, but when the Reynolds number exceeds 100 this problem doesn't occur.

Fig. 7 represent the skin friction coefficient variations versus Reynolds numbers, it will be noted that for the same Reynolds number, and despite the variation in the nanoparticles concentration volume; the $\left(\mathrm{C}_{\mathrm{f}}\right)$ value is almost identical, this confirm and supports the previous result in Fig. 5. These results, therefore, reflect the insignificant influence of the nanoparticles volume concentration on the skin friction coefficient $\left(\mathrm{C}_{\mathrm{f}}\right)$.

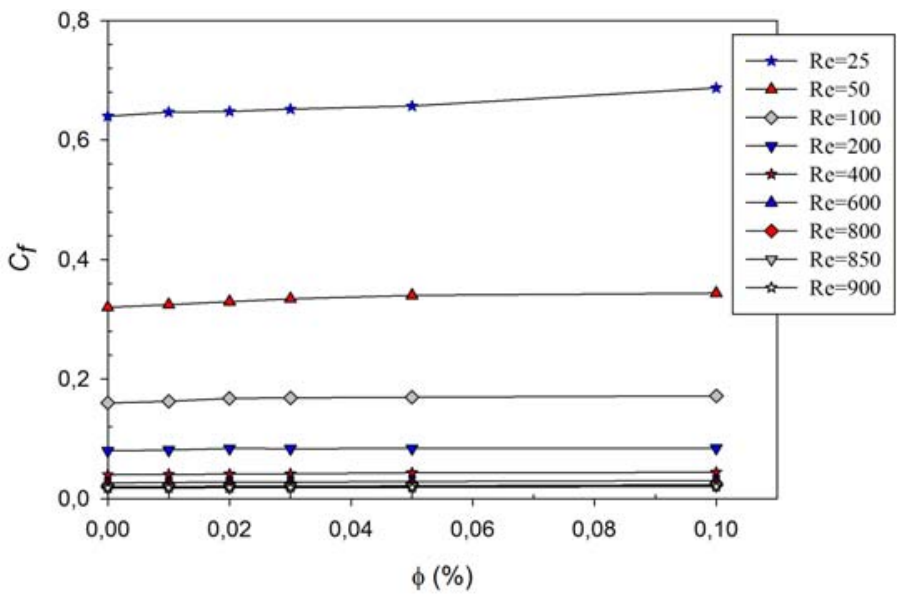

Fig. 6 Skin friction coefficient Variations versus volume fraction of $\mathrm{CuO}$ nanoparticles.

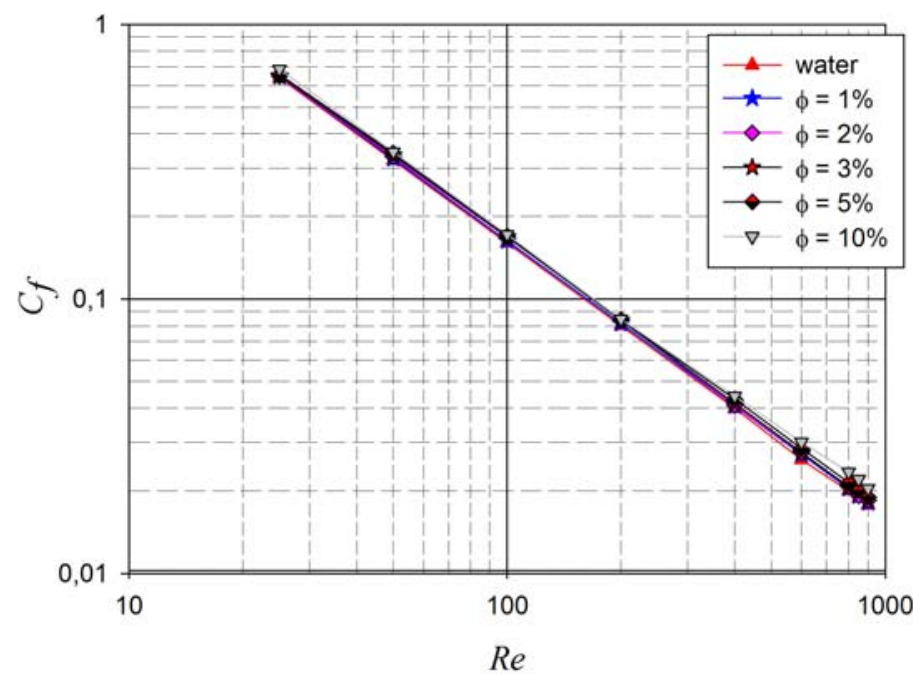

Fig. 7 Skin friction coefficient Variations versus Reynolds numbers. 


\subsection{Nusselt Number}

In this section, the numerical results of forced convection heat transfer using $\mathrm{CuO}$-water nanofluid inside a flat plate solar collector are discussed. Fig. 8, represents Nusselt number evolution of "Nu" as a function of the nanoparticles volume fraction " $\phi$ ". We note a significant increase of Nusselt number with the increase in $\mathrm{CuO}$ nanoparticle volume concentration for all its value.

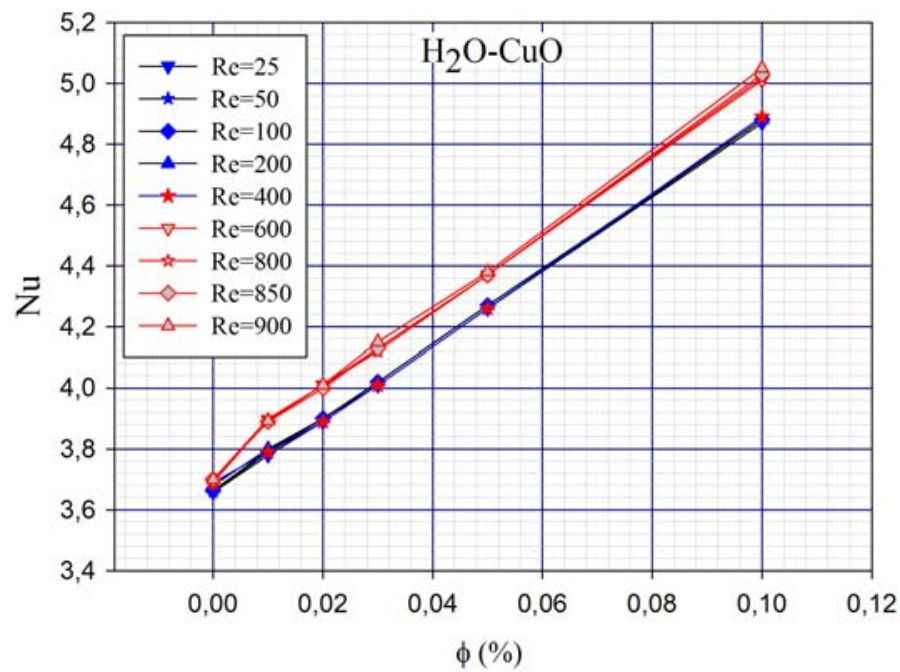

Fig. 8 Heat transfer coefficient Variations versus $\mathrm{CuO}$ nanoparticles volume concentrations.

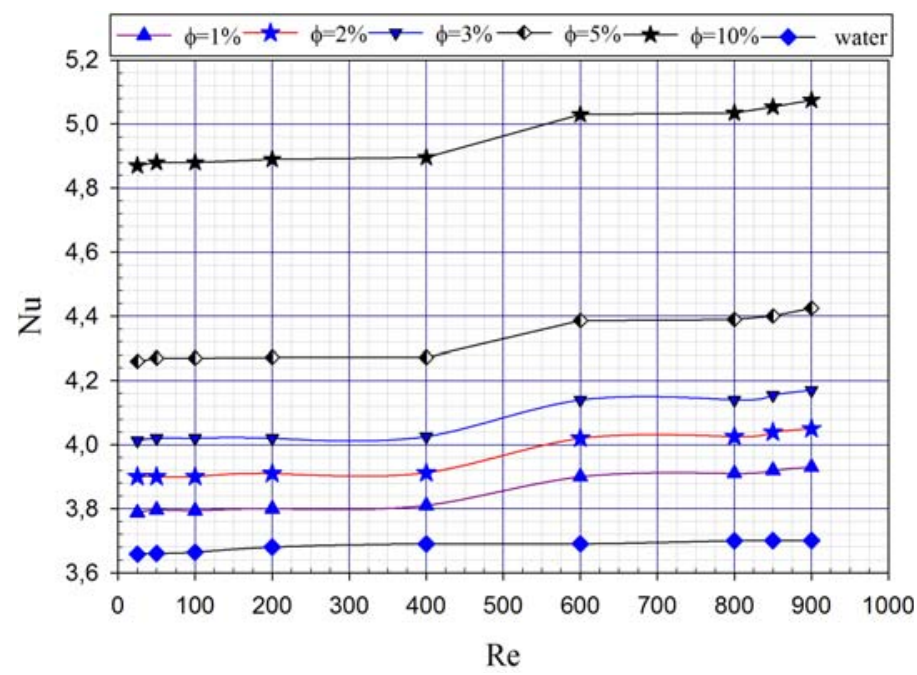

Fig. 9 Heat transfer coefficient Variations versus $\mathrm{CuO}$ nanoparticles volume concentrations.

The effect of Reynolds number on heat transfer coefficient $(\mathrm{Nu})$ is illustrated in Fig. 8 for both pure water and the $\mathrm{CuO}$-water nanofluide, a slight increase in Nusselt when the Reynolds number is low $(\operatorname{Re} \leq 400)$, but when the Reynolds number exceeds this value, each increase in Reynolds number is accompanied with an increase brusque in Nusselt number, this increase in $\mathrm{Nu}$ is due to the presence of nanoparticles Brownian-motion for higher fluid flow velocities, consequently the heat transfer intense through the working fluid increase.

Fig. 9 represents the comparison in term of rate improvement of heat transfer coefficient for various $\mathrm{CuO}$ nanoparticles volume concentrations. We notice then, a considerable increase of the improvement rate compared to pure water which can reach an average value of $34.7 \%$ for $\phi=10 \%$.

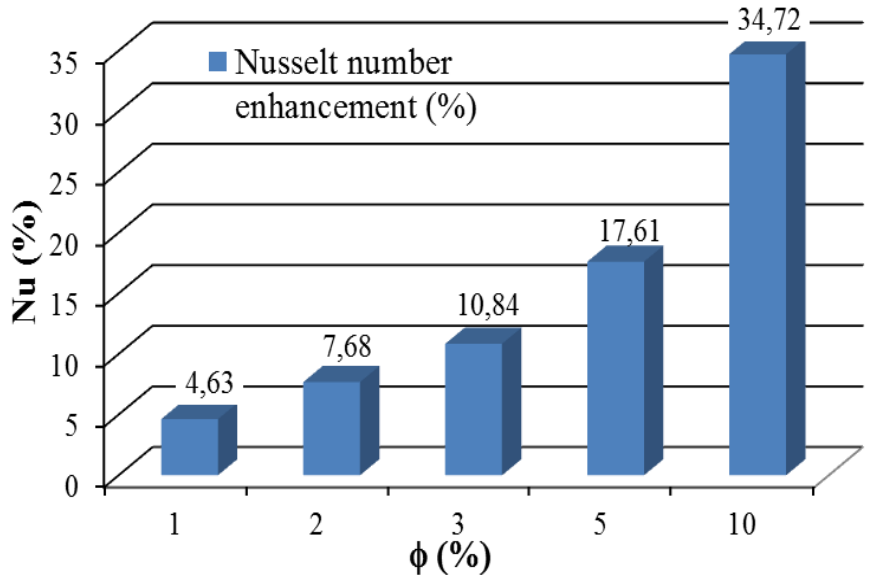

Fig. 10 The improvement rate of heat transfer coefficient versus $\mathrm{CuO}$ nanoparticles volume concentrations.

\section{CONCLUSIONS}

In this paper, the flow and heat transfer characteristics of $\mathrm{CuO}$-water nanofluid for arrange of the Reynolds number (25to 900) with a wide range of volume concentration ( 0 to $10 \%)$ are studied numerically.

We can confirm from analyze of thermal-hydraulic properties of nanofluids:

- The presence of nanoparticles in the base fluid (pure water) increases significantly Nusselt number.

- Nusselt number is growing with the increase of volume fraction, the increase in heat coefficient results improve the heat transfer through the energy systems compared to the base fluid (pure water) case.

- The gain in heat is accompanied by a slight increase in skin friction coefficient for the low Reynolds numbers due to the presence of the nanoparticles and lower flow velocities, but when the Reynolds number exceeds 100 this problem doesn't occur.

The results show that, Nusselt number and heat transfer coefficient, of nanofluid are strongly dependent on nanoparticle and increase by increasing of the volume concentration of nanoparticles, and the insignificant influence of the nanoparticles volume concentration on the skin friction coefficient.

\section{ACKNOWLEDGEMENTS}

The authors wish to express their very sincerely thanks to the reviewers for their valuable and lucid comments which have improved the paper appreciably.

\section{NOMENCLATURE}

$c_{f} \quad$ skin friction coefficient

$c_{p} \quad$ specific heat $(\mathrm{J} / \mathrm{kg} \cdot \mathrm{K})$

$h \quad$ Heat transfer coefficient $\left(\mathrm{W} / \mathrm{m}^{2} \cdot \mathrm{K}\right)$

$k \quad$ thermal conductivity $(\mathrm{W} / \mathrm{m} \cdot \mathrm{K})$

$\mathrm{Nu} \quad$ Nusselt number

$q^{\prime \prime} \quad$ heat flux $\left(\mathrm{W} / \mathrm{m}^{2}\right)$

Re Reynolds number

$R \quad$ tube radius (m)

$T \quad$ temperature (K)

$u \quad$ axial velocity $(\mathrm{m} / \mathrm{s})$

Greek Symbols

$\phi \quad$ Volume concentration (\%)

$\mu \quad$ Viscosity $\left(\mathrm{kg} \mathrm{m}^{-1} \mathrm{~s}^{-1}\right)$

$\rho$ density $\left(\mathrm{kg} / \mathrm{m}^{3}\right)$

Subscripts

$f \quad$ fluid 


$\begin{array}{ll}n f & \text { nanofluid } \\ s f & \text { surface } \\ s & \text { solid }\end{array}$

\section{REFERENCES}

Al-Rashed, A.A.A.A., Kolsi, L., Kalidasan, K., Maatki, C., Borjini, M.N., Aichouni, M., Kanna, P. R., 2017, "Effect of Magnetic Field Inclination on Magneto-Convective Induced Irreversibilities in a CNTWater Nanofluid Filled Cubic Cavity," Journal of Frontier in Heat and Mass Transfer, 8, 003031.

http://dx.doi.org/10.5098/hmt.8.31

Amoura, M., Maouassi, A., and Zeraibi, N., 2012, "Heat Transfer Enhancement using CuO/Water Nanofluid," CHT-12, Proceedings of 2012 ICHMT International Symposium on Advances in Computational Heat Transfer, Bath, England.

http://dx.doi.org/10.1615/ICHMT.2012.CHT-12.530

Azmi, W.H., Sharma, K.V., Sarma, P.K., Mamat, R., Anuar, S., 2014, "Comparison of Convective Heat Transfer Coefficient and Friction Factor of $\mathrm{TiO}_{2}$ Nanofluid Flow in a Tube with Twisted Tape Inserts," Int $J$ Therm Sci, 81, 84-93.

http://dx.doi.org/10.1016/j.ijthermalsci.2014.03.002

Beyers, J.H.M., Harms T.M., et Kröger, D.G., 2001, “A Finite Volume Analysis of Turbulent Convective Heat Transfer for Accelerating Radial Flows," J. Numerical Heat Transfer, 40 (2),117-138. http://dx.doi.org/10.1080/104077801750468453

Bhushan, B., Singh, R., 2011, "Nusselt Number and Friction Factor Correlations for Solar Air Heater Duct Having Artificially Roughened Absorber Plate," Sol Energy, 85 (5), 1109-18.

http://dx.doi.org/10.1016/j.solener.2011.03.007

Boulahia, Z., Wakif, A., Sehaqui, R., 2017, "Modeling of Free Convection Heat Transfer Utilizing Nanofluid Inside a Wavy Enclosure With a Pair of Hot and Cold Cylinders", Journal of Frontier in Heat and Mass Transfer, 8, 003014.

http://dx.doi.org/10.5098/hmt.8.14

Wakif, A., Boulahia, Z., Sehaqui, R., 2017, "Numerical Analysis of the Onset of Longitudinal Convective Rolls in a Porous Medium Saturated by an Electrically Conducting Nanofluid in the Presence of an External Magnetic Field," Results in Physics, 7, 2134-2152.

https://doi.org/10.1016/j.rinp.2017.06.003

Boulahia, Z., Wakif, A., Chamkha A.J., Sehaqui, R., 2017, "Numerical Study of Natural and Mixed Convection in a Square Cavity filled by a $\mathrm{Cu}$-Water Nanofluid with Circular Heating and Cooling Cylinders," Mechanics \& Industry, 18, 502-523.

https://doi.org/10.1051/meca/2017021

Brinkman, H.C., 1952, "The Viscosity of Concentrated Suspensions and Solution," J. Chemistry Physics, 20 (4), 571-581.

http://dx.doi.org/10.1063/1.1700493

Chabane, F., Moummi, N., Brima, A., and Benramache, S., 2013, "Thermal Efficiency Analysis of a Single-Flow Solar Air Heater with Different Mass Flow Rates in a Smooth Plate," Journal of Frontier in Heat and Mass Transfer, 4 (1), 013006.

http://dx.doi.org/10.5098/hmt.v4.1.3006

Choi, S.U.S., Eastman, J. A., 1995, "Enhancing Thermal Conductivity of Fluids with Nanoparticles," IMECE1995-84938, Proceedings of 2005 ASME International Mechanical Engineering Congress and Exposition, San Francisco, CA.

Choi, S.U.S., Zhang, Z.G., Yu, W., Lockwood, F.E., Grulke, E.A., 2001, "Anomalous Thermal Conductivity Enhancement in Nanotube Suspensions," Applied Physics Letters, 79, 2252-2254.

http://dx.doi.org/10.1063/1.1408272
Eastman, J.A., Choi, S.U.S., Li, S., Thompson, L.J., Lee, S., 1997, "Enhanced Thermal Conductivity through the Development of Nanofluids," MRS1997, Proceedings of 1997 Materials Research Society Symposium, 457, 3-11. http://dx.doi.org/10.1557/PROC-457-3

Eastman, J.A., Choi, S.U.S., Li, S., Yu, W., Thompson, L.J., 2001, "Anomalously Increased Effective Thermal Conductivities of Ethylene Glycol-Based Nanoluids Containing Copper Nanoparticles," Applied Physics Letters, 78(6), 718-720.

http://dx.doi.org/10.1063/1.1341218

Evans, W., Fish, J., and Keblinski, P., 2006, "Role of Brownian Motion Hydrodynamics on Nanofluid Thermal Conductivity," Applied Physics Letters, 88(9), 093116.

http://dx.doi.org/10.1063/1.2179118

Faizal, M., Saidur, R., Mekhilef, S., Alim, M.A., 2013, "Energy, Economic and Environmental Analysis of Metal Oxides Nanofluid for Flat-Plate Solar Collector," J. Energy Conversion and Management, 76 ,162-168.

http://dx.doi.org/10.1016/j.enconman.2013.07.038

Garcia, A., Martin, R.H., Garcia, J.P., 2013, "Experimental Study of Heat Transfer Enhancement in a flat-Plate Solar Water Collector with Wire-Coil Inserts," Appl Therm Eng, 61 (2), 461-8. http://dx.doi.org/10.1016/j.applthermaleng.2013.07.048

Govindaraju, M., Ganga, B., Abdul Hakeem, A.K., 2017, "Second Law Analysis on Radiative Slip Flow of Nanofluid over a Stretching Sheet in the Presence of Lorentz Force and Heat Generation/Absorption," Journal of Frontier in Heat and Mass Transfer, 8, 003010. http://dx.doi.org/10.5098/hmt.8.10

He, Q., Zeng, S., Wang, S., 2015, "Experimental Investigation on the Efficiency of Flat-Plate Solar Collectors with Nanofluids," J. Applied Thermal Engineering, 88, 165-171.

http://dx.doi.org/10.1016/j.applthermaleng.2014.09.053

Hussein, A.K., 2015, "Applications of Nanotechnology in Renewable Energies - A Comprehensive Overview and Understanding," Renew Sustain Energy Rev, 42, 460-476. http://dx.doi.org/10.1016/i.rser.2014.10.027

Jang, S.P., and Choi, S.U.S., 2004, "Role of Brownian Motion in The Enhanced Thermal Conductivity of Nanofluids," Applied Physics Letters, 84 (21), 4316-4318.

http://dx.doi.org/10.1063/1.1756684

Juang, R., Yeh, Y., Chang, B., Chen, W., Chung, T., 2010, "Preparation of Solar Selective Absorbing Coatings by Magnetron Sputtering from a Single Stainless Steel Target," Thin Solid Films, 518 (19), 5501-04. http://dx.doi.org/10.1016/i.tsf.2010.04.025

Karanth, K., Manjunath, M., Sharma, N., 2011, "Numerical Simulation of a Solar Flat Plate Collector Using Discrete Transfer Radiation Model (DTRM) - a CFD Approach," WCE2011, In Proceedings of 2011 WCE the world congress on engineering, London, U.K.

Karthick Kumar, S., Murugesan, S., Suresh, S., 2014, "Preparation and Characterization of $\mathrm{CuO}$ Nanostructures on Copper Substrate as Selective Solar Absorbers," Mater Chem Phys, 143 (3), 1209-14. http://dx.doi.org/10.1016/j.matchemphys.2013.11.023

Karwa, R., and Chauhan, K., 2010, "Performance Evaluation of Solar Air Heaters Having v-down Discrete Rib Roughness on the Absorber Plate," J. Energy, 35 (1), 398-409.

http://dx.doi.org/10.1016/j.energy.2009.10.007

Keblinski, P., Phillpot, S.P., Choi, S.U.S., Eastman, J.A., 2002, "Mechanism of Heat Flow is Suspensions of Nano-sized Particles (nanofluids)," International Journal of Heat Mass Tranfer, 45(4), 855863. 


\section{http://dx.doi.org/10.1016/S0017-9310(01)00175-2}

Khamlich, S., McCrindle, R., Nuru, Z.Y., Cingo, N., Maaza, M., 2013, "Annealing Effect on the Structural and Optical Properties of $\mathrm{Cr} / \alpha-$ $\mathrm{Cr}_{2} \mathrm{O}_{3}$ Monodispersed Particles Based Solar Absorbers," Appl Surf Sci 265, 745-49.

http://dx.doi.org/10.1016/j.apsusc.2012.11.099

Kumar, M.S., Sandeep , N., Kumar, B.R., 2017, "Free Convective Heat Transfer of Mhd Dissipative Carreau Nanofluid Flow over a Stretching Sheet," Journal of Frontier in Heat and Mass Transfer, 8, 003013. http://dx.doi.org/10.5098/hmt.8.13

Kumar, T.S., Kumar, B.R., 2017, “A Comparative Study of Thermal Radiation Effects on Mhd Flow of Nanofluids and Heat Transfer over a Stretching Sheet", Journal of Frontier in Heat and Mass Transfer, 9, 013013.

http://dx.doi.org/10.5098/hmt.9.13

Lanjewar, A., Bhagoria, J.L., Sarviya, R.M., 2011, "Heat Transfer and Friction in Solar Air Heater Duct with W-Shaped Rib Roughness on Absorber Plate," J. Energy, 36 (7), 4531-41.

http://dx.doi.org/10.1016/j.energy.2011.03.054

Maïga, S.E.B., Nguyen, C.T., Galanis, N., et Roy, G., 2004, "Heat Transfer Behaviors of Nanofluids in Uniformly Heated Tube," Superlattices and Microstructures, 35 (3), 543-557.

http://dx.doi.org/10.1016/j.spmi.2003.09.012

Maouassi, A., Baghidja, A., Daoud, S., Zeraibi, N., 2017, "Numerical Study of Nanofluid Heat Transfer $\mathrm{SiO}_{2}$ Through a Solar Flat Plate Collector," International Journal of Heat and Technology, 35 (3), 619625.

http://dx.doi.org/10.18280/ijht.350319

Maxwell, J.C., 1891, A Treatise on Electricity and Magnetism. Clarendon Press. Oxford, UK.

Menbari, A., Alemrajabi, A.A., Rezaei, A., 2016, "Heat Transfer Analysis and the Effect of $\mathrm{CuO} /$ Water Nanofluid on Direct Absorption Concentrating Solar Collector," J. Applied Thermal Engineering, 104, 176-83.

http://dx.doi.org/10.1016/j.applthermaleng.2016.05.064

Nanan, K., Thianpong, C., Promvonge, P., Eiamsa-ard, S., 2014, "Investigation of Heat Transfer Enhancement by Perforated Helical Twisted-Tapes," Int Commun Heat Mass Transf, 52, 106-12. http://dx.doi.org/10.1016/j.icheatmasstransfer.2014.01.018

Nasrin, R., Alim, M. A., Ahmed, S. R., 2016, "Comparative Study between 2D and 3D Modeling of Nanofluid Filled Flat Plate Solar Collector," International Journal of Heat and Technology, 34, 604-10. http://dx.doi.org/10.18280/ijht.340326

Natarajan, E., and Sathish, R., 2009, "Role of Nanofluids in Solar Water Heater," Int J. Adv Manuf Technol, 45, 1-5.

http://dx.doi.org/10.1007/s00170-008-1876-8

Nuru, Z., Arendse, C.J., Khamlich, S., Maaza, M., 2012, “Optimization of $\mathrm{Al}_{\mathrm{x}} \mathrm{O}_{\mathrm{y}} / \mathrm{Pt} / \mathrm{Al}_{\mathrm{x}} \mathrm{O}_{\mathrm{y}}$ Multilayer Spectrally Selective Coatings for SolarThermal Applications," J. Vacuum, 86 (12), 2129-35.

http://dx.doi.org/10.1016/j.vacuum.2012.06.012

Otanicar, T.P., Phelan, P.E., Prasher, R.S., Rosengarten, G., Taylor, R.A., 2010, "Nanofluid-Based Direct Absorption Solar Collector," J. Renewable and Sustainable Energy, 2 (3), 1-13.

http://dx.doi.org/10.1063/1.3429737
Pak, B.C., and Cho, Y. I., 1998, "Hydrodynamic and Heat Transfer Study of Dispersed Fluids with Submicron Metallic Oxide Particles," $J$. Experimental Heat Transfer, 11(2), 151-170.

http://dx.doi.org/10.1080/08916159808946559

Patel, H.E., Das, S.K., Undararajan, T., Nair, A.S., George, B., Pradeep, T., 2003, "Thermal Conductivities of Naked and Monolayer Protected Metal Nanoparticle Based Nanoluids: Manifestation of Anomalous Enhancement and Chemical Effects", Applied Physics Letters, Vol. 83(14), 2931-2933.

http://dx.doi.org/10.1063/1.1602578

Patankar, S.V., 1980, Numerical Heat Transfer and Fluid Flow. McGraw-Hill Book, New York, USA.

Promvonge, P., Pethkool, S., Pimsarn, M., Thianpong, C., 2012, "Heat Transfer Augmentation in a Helical-Ribbed Tube with Double Twisted Tape Inserts," Int Commun Heat Mass Transf, 39 (7), 953-59. http://dx.doi.org/10.1016/j.icheatmasstransfer.2012.05.015

Ramesh, G.K., and Gireesha, B.J., 2017, "Non-Linear Radiative Flow of Nanofluid Past a Moving/Stationary Riga Plate," Journal of Frontier in Heat and Mass Transfer, 9, 013003.

http://dx.doi.org/10.5098/hmt.9.3

Rawi, N.A., Kasim, A.R.M., Isa, Z.M., Mangi, A., Shafie, S., 2017, "GJitter Effects on the Mixed Convection Flow of Nanofluid Past an Inclined Stretching Sheet," Journal of Frontier in Heat and Mass Transfer, 8, 003012.

http://dx.doi.org/10.5098/hmt.8.12

Sandhu, G., Siddiqui, K., Garcia, A., 2014, "Experimental Study on the Combined Effects of Inclination Angle and Insert Devices on the Performance of a flat-Plate Solar Collector," Int J Heat Mass Transf, 71, 251-63.

http://dx.doi.org/10.1016/j.ijheatmasstransfer.2013.12.004

Sokhansefat, T., Kasaeian, A. B., Kowsary F., 2014, "Heat Transfer Enhancement in Parabolic Trough Collector Tube Using $\mathrm{Al}_{2} \mathrm{O}_{3} /$ Synthetic Oil Nanofluide," J. Renewable and Sustainable Energy Reviews, 33, 636-644.

http://dx.doi.org/10.1016/j.rser.2014.02.028

Srinivasacharya, D., Shafeeurrahaman, M., 2017, "Mixed Convection Flow of Nanofluid in a Vertical Channel with Hall and Ion-Slip Effects," Journal of Frontier in Heat and Mass Transfer, 8, 003011.

http://dx.doi.org/10.5098/hmt.8.11

Tagliafico, I.A., Scarpa, F., and Rosa, M.D., (2014), "Dynamic Thermal Models and CFD Analysis for Flat-Plate Thermal Solar Collectors - A Review," Renew and Sust Energy Rev, 30, 526-537. http://dx.doi.org/10.1016/j.rser.2013.10.023

Xuan, Y., Roetzel, W., 2000, "Conception for Heat Transfer Correlation of Nanofluids," Int J. Heat and Mass Transfer, 43(19), 3701-3707.

http://dx.doi.org/10.1016/S0017-9310(99)00369-5

Yadav, S., Kaushal, M., Varun, S., 2013, "Nusselt Number and Friction Factor Correlations for Solar Air Heater Duct Having Protrusions as Roughness Elements on Absorber Plate," Exp Therm Fluid Sci, 44, 3441.

http://dx.doi.org/10.1016/j.expthermflusci.2012.05.011

Zhou, S. Q., Ni, R., 2008, "Measurement of the Specific Heat Capacity of Water-Based $\mathrm{Al}_{2} \mathrm{O}_{3}$ Nanofluid," Appl Phys Lett, 92 (9), 0931231. http://dx.doi.org/10.1063/1.2890431 